\title{
Comparison of general anesthesia with spinal application in arthroscopic knee surgery regarding hemodynamic parame- ters
}

\section{Diz artroskopisinde spinal anestezi ile genel anestezinin hemodinamik parametreler açısından karşılaştırılması}

Adem Yılmaz ${ }^{1}$ *Mustafa Muhlis Alparslan², Neşe Aydın

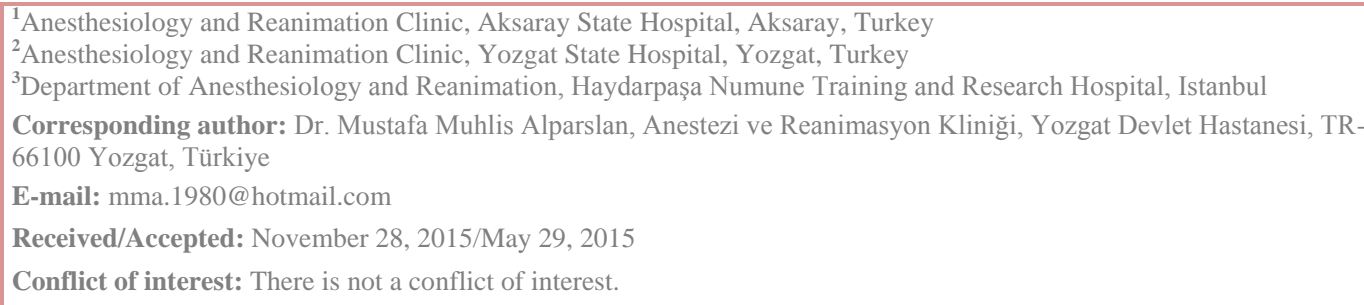

\section{SUMMARY}

Objective: We aimed to compare general anesthesia applied with the combination of propofoldesfluran and single-sided spinal anesthesia with regards to hemodynamic parameters and discharge criteria. in patients undergoing daily arthroscopic knee surgery

Methods: Cases were divided randomly into two groups. Group 1 (n: 20) is specified as general anesthesia group and Group 2 (n: 20) is specified as spinal anesthesia group. General anesthesia with propofol-desfluran has been applied to patients of Group 1 and spinal anesthesia with $10 \mathrm{mg}$ $0.5 \%$ hyperbaric bupivacaine has been applied to the patients of Group 2.

Results: Modified Aldrete Scores related to the patients of Group 2 were statically significantly lower than Group 1 because of the ongoing motor block. PADSS and Emesis Scores were similar in both groups. Starting of pain was statistically within a longer period in patients with Group 2 when compared to group 1 due to the ongoing organoleptic block. The differences in hemodynamic parameters between two groups were in concordance with the anesthesia method applied.

Conclusion: It is concluded that one-sided spinal anesthesia provided with low dosed $0.5 \%$ hyperbaric bupivacaine intrathecal injection may be a good alternative to general anesthesia with propfol-desfluran. in patients undergoing daily arthroscopic knee surgery when its significant contribution to analgesia in postoperative period is considered.

Keywords: General anesthesia, spinal anesthesia, hemodynamic parameters, discharge criteria

\section{ÖZET}

Amaç: Günübirlik artroskopik diz cerrahisi uygulanan hastalarda spinal anestezi ile genel anestezinin hemodinamik parametreler ve taburculuk kriterleri açısından karşılaştırılmasını amaçladik.

Yöntem: Olgular randomize olarak iki gruba ayrıldı. Grup 1 (n: 20) genel anestezi grubu, Grup 2 (n:20) spinal anestezi grubu olarak belirlendi. Grup 1 hastalarına propofol-desfluran ile genel anestezi, Grup 2 hastalarına ise $10 \mathrm{mg} \% 0,5$ hiperbarik bupivakain ile spinal anestezi uygulanmıştır.

Bulgular: Grup 2'deki hastaların devam eden motor blok nedeniyle Modifiye Aldrete Skorları, 
Grup 1'deki hastalardan istatistiksel olarak anlamlı derecede düşüktü. PADSS ve Emezis Skorlar1 ise her iki grupta benzerdi. Grup 2'deki hastalarda devam eden duyusal blok nedeniyle Grup 1'deki hastalara göre ağrı başlama zamanları istatistiksel olarak ileri derecede uzundu. İki grup arasındaki hemodinamik parametrelerdeki farklılıklar uygulanan anestezi şekliyle uyumluydu.

Sonuç: Günübirlik artroskopik diz cerrahisi uygulanan hastalarda düşük doz \%0,5 hiperbarik bupivakainin intratekal enjeksiyonu ile sağlanan tek taraflı spinal anestezi uygulamasının özellikle postoperatif dönemdeki analjeziye olan önemli katkısı göz önünde tutulunca propofol-desfluran ile sağlanan genel anestezi uygulamasına iyi bir alternatif olabileceği kanaatine varıldı.

Anahtar sözcükler: Genel anestezi, spinal anestezi, hemodinamik parametreler, taburculuk kriterleri

\section{INTRODUCTION}

Patients underwent joint arthroscopy are usually discharged in the same day of process. Although, patients are commonly considered as a young and sportsman, knee arthroscopy is also freguently used in elderly patients with a variety of health problems ${ }^{1}$.

All anesthesia techniques can be applied in one-day surgery when a proper selection of technique was achieved considering both patient and type of surgery. There are a number of advandeges using spinal anesthesia (SA) including an easy application, better cost-effectiveness ratio, minimal effect on vital functions (if a sufficient volume support was provided before SA), non-occurrence of complications such as possible airway problems related to general anesthesia and postoperative sore throat. Therefore, SA is increasingly preferred in one-day surgery cases $^{2,3}$.

The objective of this study was to compare unilateral SA provided by intrathecal $0.5 \%$ hyperbaric bupivacaine to GA performed by a combination of propofol-desflurane regarding hemodynamic parameters and discharge criteria in patients undergoing arthroscopic knee surgery.

\section{MATERIAL AND METHODS}

After obtaining ethical approval, patients who were planned to undergo an elective arthroscopic knee surgery and aged between 18 and 70 were included in this study. It was conducted as a randomised study in a single center on the number of 40 patients that were in I-II category regarding American Society of Anesthesiologists (ASA) phsical status criteria.

Patients with any of following health problems were excluded from the study. These medical issues include decompensated cardiac disease, severe liver, kidney and lung disorder, a history of malignant hyperthermia, decompensated diabetes mellitus, long-term starvation, being chronic alcoholics, morbidly obese, having a known or suspected history of convulsion and sensitivity against propofol, bupivacaine or desflurane and a severely decreased regional blood supply, receivement of intensive blood transfusion, malignancy, hypovolemia, shock, dehydration, presence or suspection of cerebrovascular hemorrhage, increased intracranial pressure syndrome, head trauma, unconsciousness with unknown cause, respiratory dysfunction, prolonged operation period longer than 2 hours.

$18 \mathrm{G}$ cannula was placed into a vein of patients in the preparation room in the theatre and patients received a fluid replacement therapy by isolyte-M 6-8 $\mathrm{mL} / \mathrm{kg}$. Individuals were randomly divided into two groups. GA was applied to patients participated in group $1 \quad(n=20)$ whilst pateints received SA included in group $2 \quad(n=20)$. Following preoxygenation with $100 \% \mathrm{O}_{2}$ for about 3 minutes, general anesthesia was induced in patients by administration of intravenous 1 $\mathrm{mcg} / \mathrm{kg}$ fentanyl, $2-2.5 \mathrm{mg} / \mathrm{kg}$ propofol and $0.1 \mathrm{mg} / \mathrm{kg}$ vecuronium. After orotracheal intubation, maintenance of anesthesia was achieved by desflurane $4-6 \%$ in combination with $50-50 \% \quad \mathrm{O}_{2}-\mathrm{N}_{2} \mathrm{O}$ fresh gas mixture. Systolic arterial pressure (SAP), diastolic arterial pressure (DAP), mean arterial pressure (MAP), heart rate (HR) and blood oxygen saturation $\left(\mathrm{SpO}_{2}\right)$ values were noted at $5,10,15,20,25,30$, $40,50,60,75,90$ and $120^{\text {th }}$ minutes after intubation. In addition, patients incuded in group 2 were brought to the lateral position 
regarding operation side to be left at the bottom and SA was performed by administration of $10 \mathrm{mg}$ hyperbaric bupivacaine through $25 \mathrm{G}$ cannula placed into the subarachnoid space at L3-4 intervertabral space. The patients were brought into the supine position after standing in this position for 10 minutes. All patients received a standard of $2 \mathrm{lt} \mathrm{O}_{2} /$ per minute through nasal cannula and administered $\quad 0.003 \mathrm{mg} / \mathrm{kg}$ intravenous midazolam for sedation. SAP, DAP, MAP, $\mathrm{HR}$ and $\mathrm{SpO}_{2}$ values were recorded at 5 , $10,15,20,25,30,40,50,60,75,90$ and $120^{\text {th }}$ minutes after administration of spinal injection. Levels of sensory and motor block were assessed by both pinprick test and Bromage Scale, respectively from $3^{\text {rd }}$ minute after intrathecal injection. Individuals participated in both groups we reevaluated in recovery room (regarding
Modified Aldrete Score) and patient's services (considering Emesis Score and PADSS) in post-operative period. Postoperative hemodynamic parameters, possible side effects of anesthetic agents, quality of recovery and discharge criteria were compared in both groups. Patients with Modified Aldrete Score higher than 8 $(\geq 8)$ were sent from a recovery room to service.

Following re-assessment of patients in the services, individuals with Emesis Score 0 or 1 and PADSS higher than $9(\geq 9)$ were considered to be discharged.

Table 1: Abramowitz emesis score.

\begin{tabular}{l|l}
\hline None & 0 \\
Mild (once) & 1 \\
Moderate (twice) & 2 \\
Severe (4 times) & 3 \\
Persistant & 4 \\
\hline
\end{tabular}

Table 2: Modified aldrete score.

\begin{tabular}{l|l|l|}
\hline Physical activity (free movement or & 4 extremities & 2 \\
movement with command) & 2 extremities & 1 \\
& 0 extremity & 0 \\
Respiratory stability & Able to breathe deeply with good cough & 2 \\
& Dispneic, superficial breathing & 1 \\
Hemodynamic stability & Apneic & 0 \\
& Blood pressure $+-20 \mathrm{mmHg}$ preanesthetic period & 2 \\
& Blood pressure $+-20-50 \mathrm{mmHg}$ preanesthetic period & 1 \\
Level of consciousness & Blood pressure $+-50 \mathrm{mmHg}$ preanesthetic period & 0 \\
& Awake and oriented & 2 \\
Oxygen saturation status & Responsive only to tactile stimulation & 1 \\
& No response & 0 \\
& Maintance value $\geq 92 \%$ on room air & 2 \\
& For $90 \% \mathrm{SpO}_{2}$, requirement of $\mathrm{O}_{2}$ inhalation & 1 \\
\hline
\end{tabular}

\section{Statistical analysis}

NCSS Statistical Software 2007\&PASS 2008 (Utah, USA) was used for statistical analysis of results collected in this study. In addition to descriptive statistical methods (mean, standard deviation), Student's test was used in quantitative comparison of parameters between two groups revealing normal distribution whilst Mann Whitney $U$ test was applied to compare parameters that do no exhibit normal distrubition between two groups. Moreover, parameters showing abnormal distrubition with in group were analysed by Wilcoxon sign test. On the other hand, Fisher's exact test and chi square test was used for comparison of qualitative data. Results were evaluated in $95 \%$ confidence interval and $\mathrm{p}$ value lower than 0.05 $(p<0.05)$ level refered to show significance 
Table 3: Postanesthetic Discharge Scoring System (PADSS).

\begin{tabular}{l|l}
\hline \multicolumn{2}{c}{ Vital signs } \\
\hline Vital signs should be stable and in concordance with age and pre-operative values. \\
\hline BP and HR within $20 \%$ of pre-operative value & 2 \\
BP and HR within $20-40 \%$ of pre-operative value & 1 \\
BP and HR within $>40 \%$ of pre-operative value & 0 \\
\hline
\end{tabular}

\section{Activity status}

Patient should maintance pre-operative capacity of activity.

Steady gait and none of nausea

Requirement of help

Immobile

2

\section{Nause and/or vomiting}

Nausea and vomiting should be at minimal level in patient prior to be discharged.

Minimal: Successful treatment with per oral (PO) medication

Moderate: Successful treatment with intramuscular (IM) injection

Severe: persistant in spite of repeated treatment

\section{Pain}

Pain should be absent or minimal before discharge.

Pain level should be tolerable.

Pain should be taken under control by oral analgesics.

Location, type and severity of pain should be in concordance with anticipated post-operative complication.

Acceptability

Yes

No

\section{2}

1

0

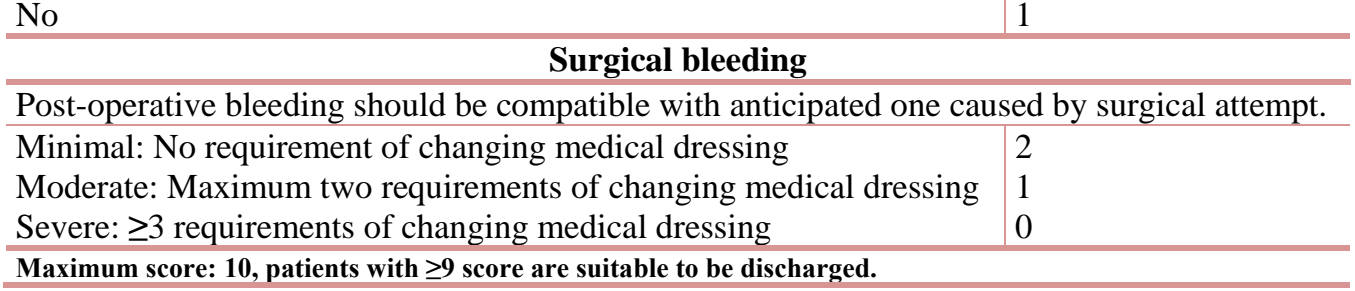

\section{RESULTS}

Mean age of patients is $44.65 \pm 12.75$. Individuals were assessed in two groups that were generated based on the administration route of anesthesia including general anesthesia $(n=20)$ and spinal anesthesia $(n=20)$. There was not any significant difference between age, length, weight and distribution of gender in patients received different anesthesia (Table 4). Moreover, a statistically remarkable changes were not determined between two groups when considering duration of operation and turniquet, distribution of ASA, region of operation and occurrence ratio of peroperative complications(bradicardia, hypotension).
Systolic arterial blood pressure (SAP) was determined significantly lower in group 1 then group 2 at 5 th minute $(\mathrm{p}<0.05)$ (Figure 1). Moreover, decrease in SAP values went deeper in group 1 at 10 and 15 th minutes $(p<0.01)$. However, there was not any statistically remarkable changes in SAP values at any time point in the resting period (Figure 1).

Table 4: Assessment of personal features regarding type of anesthetic administration.

\begin{tabular}{lll|l}
\hline & Group 1 & Group 2 & P values \\
\cline { 2 - 4 } & Mean \pm SD & Mean \pm SD & \\
\hline Age & $42.45 \pm 12.50$ & $46.85 \pm 12.93$ & 0.281 \\
Lenght $(\mathrm{cm})$ & $167.30 \pm 6.53$ & $169.80 \pm 8.91$ & 0.318 \\
Weight $(\mathrm{kg})$ & $76.60 \pm 10.15$ & $80.65 \pm 12.25$ & 0.262 \\
\hline Gender & $\mathbf{n}(\boldsymbol{\%})$ & $\mathbf{n}(\%)$ & \\
\hline Male & $8(\% 40.0)$ & $10(\% 50,0)$ & 0.525 \\
Female & $12(\% 60.0)$ & $10(\% 50.0)$ & \\
\hline
\end{tabular}




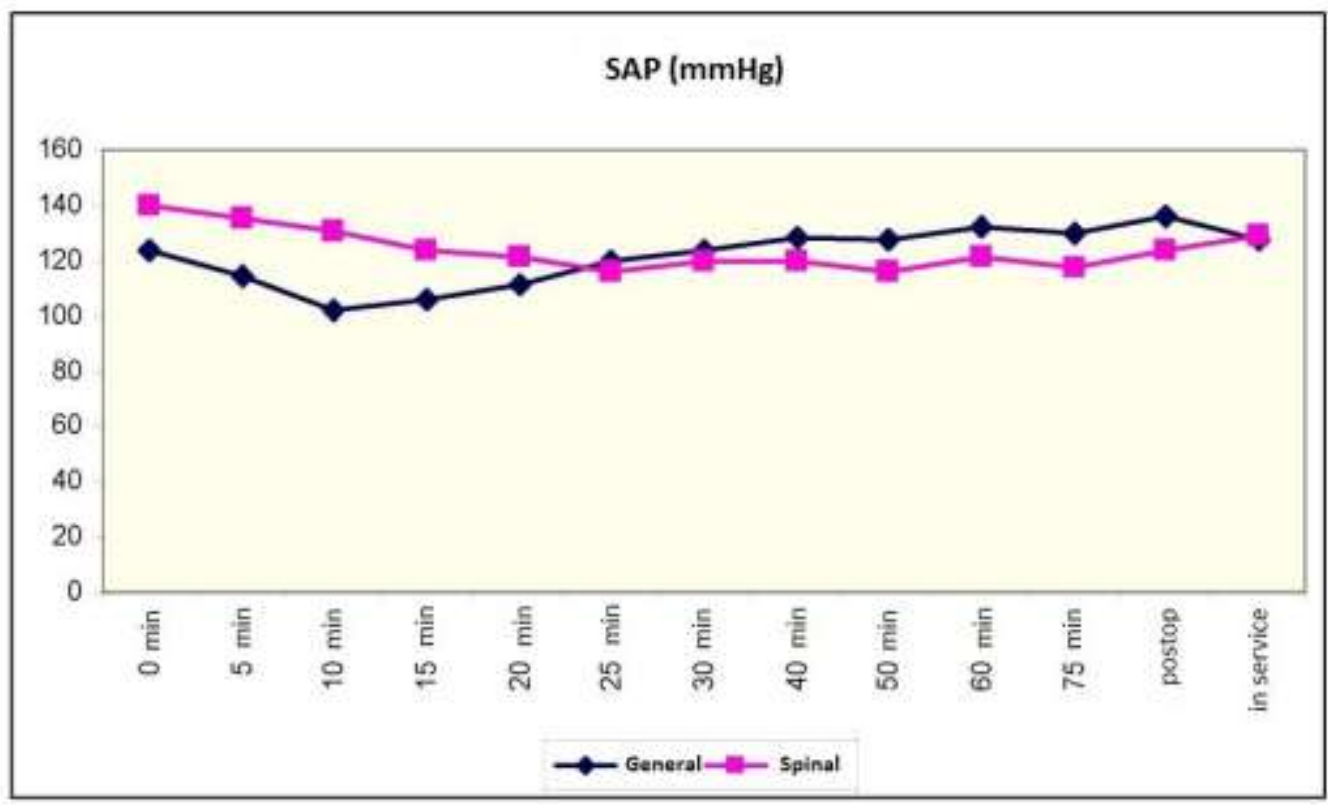

Figure 1: Changes recorded in SAP values regarding type of anesthetic administration.

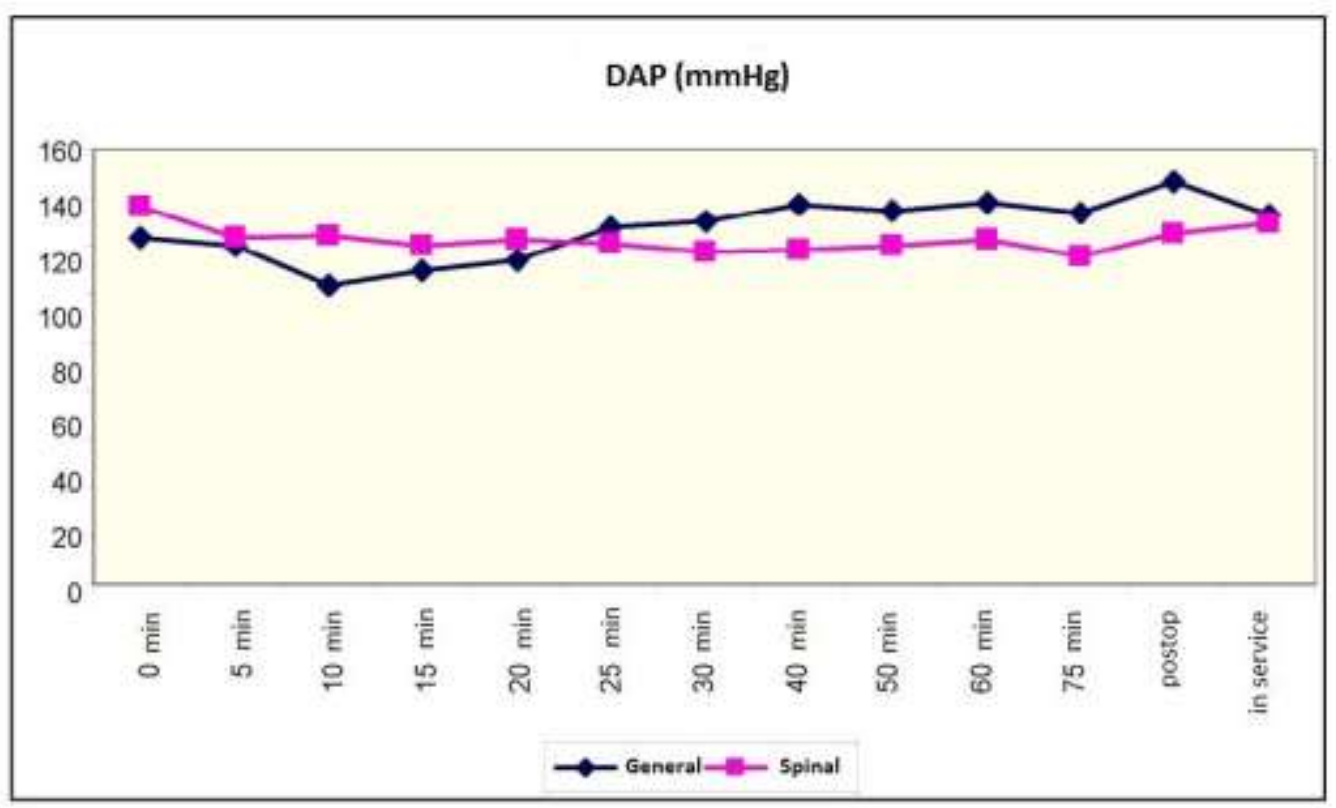

Figure 2: Changes recorded in DAP values regarding type of anesthetic administration. 


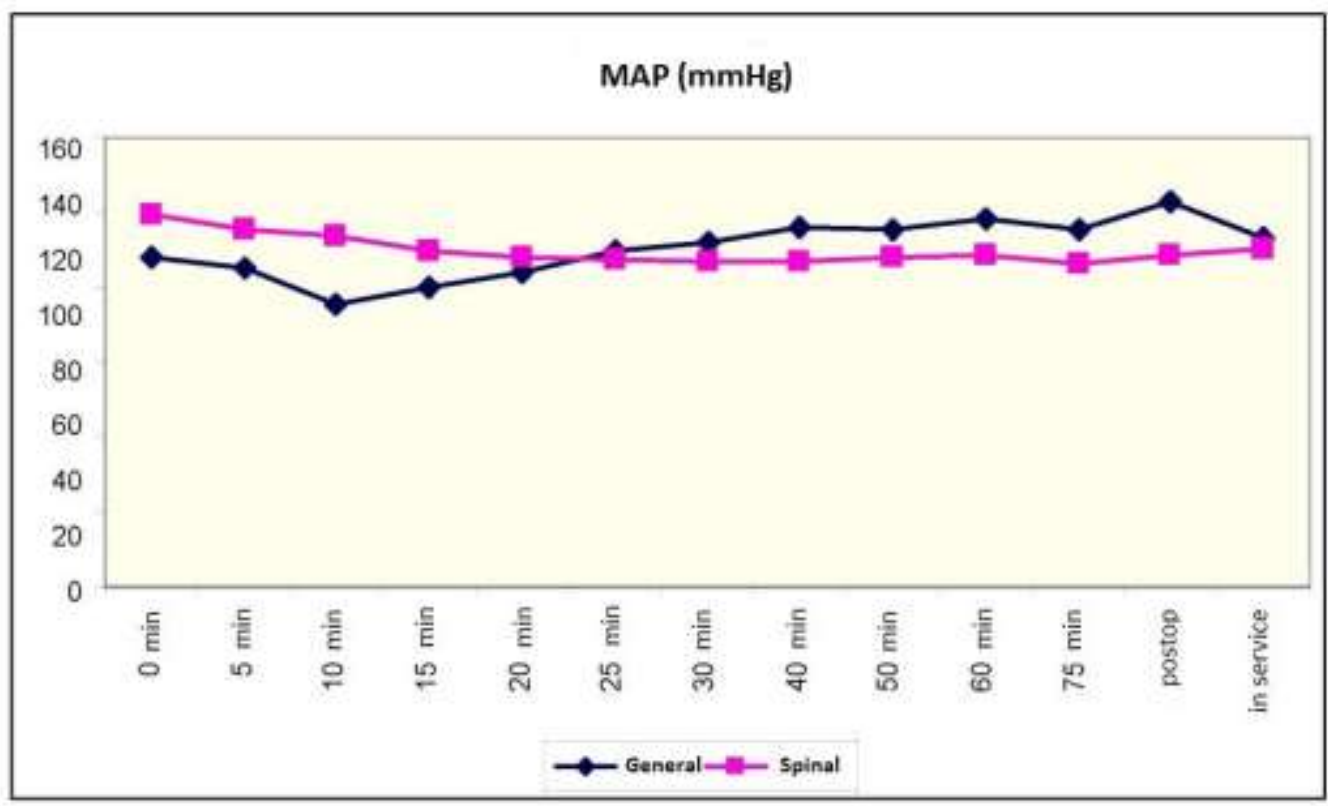

Figure 3: Changes recorded in MAP values regarding type of anesthetic administration.

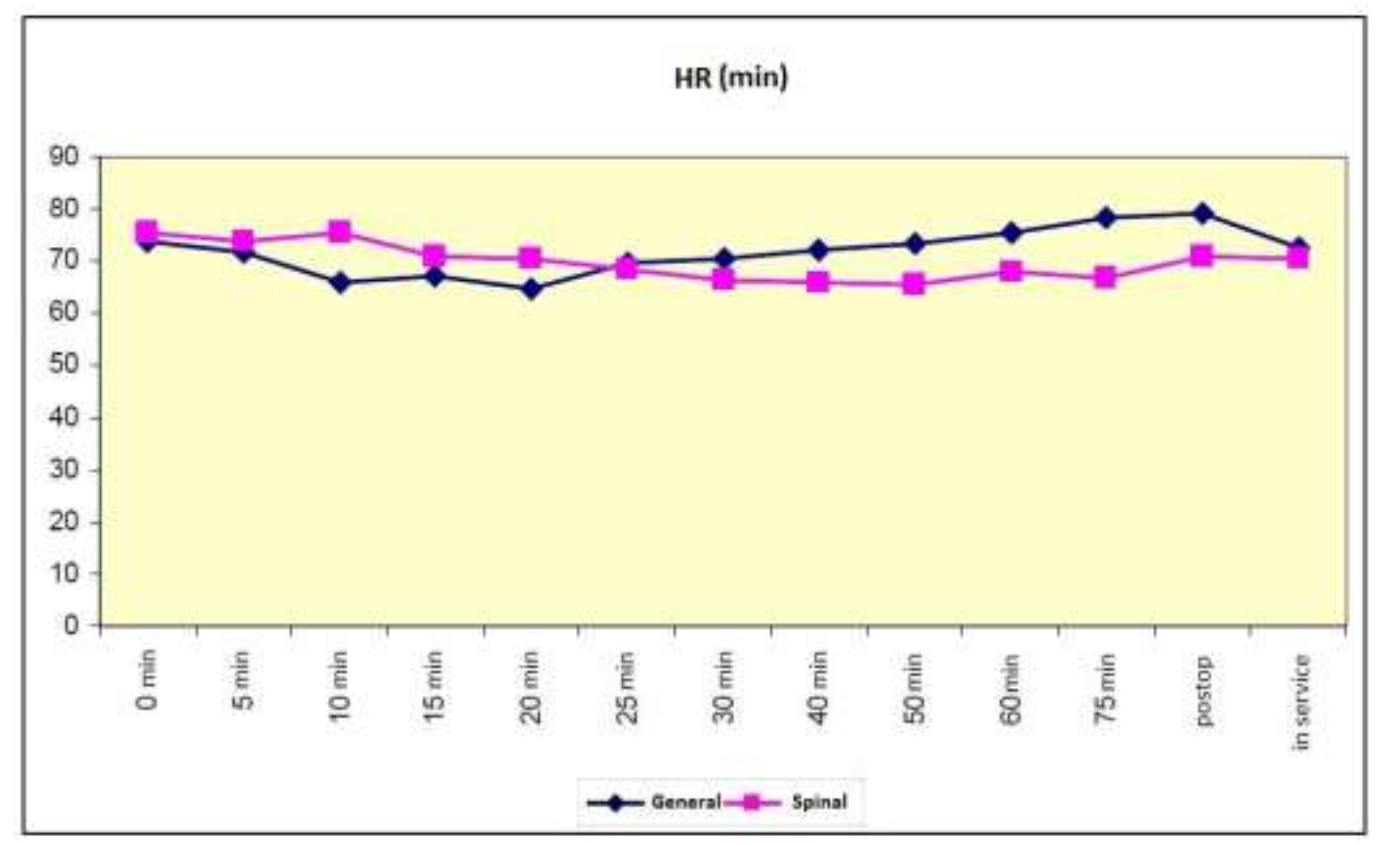

Figure 4: Changes recorded in heart beat rate (HR) values regarding type of anesthetic administration.

Table 5. Assessment of patients by modified aldrete scoring system, PADSS and emesis scoring scales regarding type of anesthetic administration.

\begin{tabular}{l|ll|l}
\hline & Group 1 & Group 2 & P values \\
\cline { 2 - 4 } & Mean \pm SD (median) & Mean \pm SD (Median) & \\
\hline Modified aldrete & $9,65 \pm 0,49(10)$ & $8.55 \pm 0.51(9)$ & $0.001^{* *}$ \\
PADSS & $9,95 \pm 0,22(10)$ & $9.80 \pm 0.41(10)$ & 0.157 \\
Emesis score & $0 \pm 0(0)$ & $0.05 \pm 0.22(0)$ & 0.317 \\
\hline
\end{tabular}


Furthermore, there was a statistically significant decrease in the diastolic arterial blood pressure (DAP) in group 1 at $10^{\text {th }}$ minute in comparison to values collected in group $2(\mathrm{p}<0.05)$ (Figure 2$)$. On the other hand, post-operative DAP values were remarkably higher in group 1 when compared with those in group $2(\mathrm{p}<0,05)$. However, there was not any statistically significant differences in DAP values at any time point in the resting period (Figure 2 ). Additionally, a statistically remarkable attenuation was observed in the mean arterial blood pressure (MAP) in group 1 at $10^{\text {th }}$ minute compared to values recorded for patient participated in group $2(\mathrm{p}<0.05)$ (Figure 3). On the other hand, postoperative MAP values were determined to be significantly increased in group 1 in comparison to group $2(\mathrm{p}<0.05)$. However, there was not any statistically significant differences in MAP values at any time point in the resting period (Figure 3 ). In addition, heart beat rate (HR) was found to be statistically decreased at 10 and $20^{\text {th }}$ minutes in patients included in group 1 in comparison to those participated in group 2 $(\mathrm{p}<0.05)$ (Figure 4). On the other hand, an elevation in HR values was recorded for group 1 participants at $50,60,75^{\text {th }}$ minutes and in post-operative period when they compared to values collected in group 2 $(\mathrm{p}<0.05)$. However, there was not any statistically significant differences in HR values at any time point in the resting period (Figure 4).

On the other hand, a statistically significant difference was not determined at any time point when comparing collected $\mathrm{SpO}_{2}$ values to baseline levels in each group or between two groups. Modified Aldrete Scores of group 1 patients was determined significantly increased comparing to those in group 2 $(\mathrm{p}<0.01)$ (Table 5). However, there was not any remarkable difference between patients when mean \pm SD (median) values were compared within two groups regarding PADSS and emesis scores (Table 5).

\section{DISCUSSION}

Use of conventional doses of spinal anesthetic agents results in delayed discharge time of outpatients from the hospital in comparison to pateints received general anesthesia ${ }^{4,5}$. In order to overcome this issue; use of low doses of long-acting local anesthetics or combination of local anesthetics with intrathecal opioids and application of unilateral SA may be thought in patients required SA. It was suggested that use of long-acting local anesthetics such as bupivacaine at low dose results in an increased interest in this matter ${ }^{6}$. However, administration of lowdose SA may cause a high failure rate ${ }^{7,8}$. Morever, Enk et $\mathrm{al}^{9}$ suggested that use of low dose of local anesthetics with both low volume and flow rate in addition to giving lateral decubitus position to the patients for 5-30 minutes is the most successful method to achieve unilateral SA. We also maintained patients participated in group 2 at lateral decubitus position for 10 minutes after SA application followed by bringing individuals into the supine position. None of the patients felt pain or required additional anesthesia during the surgery.

Toker et $\mathrm{al}^{10}$ compared different anesthetic method including general, spinal anesthesia and peripheral nerve block on 42 patients undergoing arthroscopic knee surgery. In this study, individuals participated in SA group delivered intrathecal $10 \mathrm{mg} \quad(2 \mathrm{~mL})$ of $0.5 \%$ hyperbaric bupivacaine through $25 \mathrm{G}$ cannula at lateral decubitus position. None of patients suffered from intra-operative pain or required additional analgesics. Volume replacement was done by 10 $\mathrm{mL} / \mathrm{kg}$ Ringer's lactate solution before performing spinal block in patients. In addition, none of individuals developed intra-operative hypotension that required ephedrine treatment. Urinary catheter was inserted in only one patient with urinary retention in post-operative period.

Moreover, postdural puncture headache (PDPH) was not observed in any patient. Recently, Bhat et $\mathrm{al}^{11}$. applied intrathecal $7.5 \mathrm{mg}$ of $0.5 \%$ hyperbaric bupivacaine in spinal group`s patients and suggested that none of them had an intra-operative pain. It was reported in the same study that there is not a significant difference between groups regarding PADSS and emesis scores ${ }^{11}$. 
In our study, spinal block was successfully achieved in all patients of group 2. We also observed that none of the patients participated in group 2 felt intra-operative pain or required additional anesthesia during the surgery. Intra-operative hypotension developed in three patients $(15 \%)$. We suggest that it might be caused by an insufficient volume replacement $(7 \mathrm{ml} / \mathrm{kg})$ prior to spinal block. In the postoperative period, one patient suffered from PDPH. Urinary catheter was inserted at post-operative $4^{\text {th }}$ hour in two patients that could not urinate and felt embarrassment. There was not any significant difference between groups regarding PADSS and emesis scores (Table 5). These results were consistent with the study.

On the other hand, there is not any consensus on the discharge timing of patients that underwent knee arthroscopy by administrating similar dose for unilateral spinal anesthesia. Korhonen et $\mathrm{al}^{12}$. compared two groups of patients received either $4 \mathrm{mg}$ hyperbaric bupivacaine or propofol-desflurane and determined mean of time for being ready to discharge as 112 and 107 minutes, respectively. Moreover, Mulroy et $\mathrm{al}^{4}$. suggested discharge timing in patients that were administered by $75 \mathrm{mg}$ procaine and $10-20 \mathrm{mcg}$ fentanyl as 146 and 104 minutes, respectively. Koltka et $\mathrm{al}^{13}$. also compared delivery of anesthetic agent, $5 \mathrm{mg}$ hyperbaric bupivacaine to propofoldesflurane and postulated discharge time as 120 and 100 minutes, respectively. Time of discharge in patients administered by either $15 \mathrm{mg}$ and $7.5 \mathrm{mg}$ bupivacaine was determined as 471 and 202 minutes, respectively ${ }^{7}$. In addition, Casati et $\mathrm{al}^{14}$ detected it as 179 minutes in the study conducted by using $8 \mathrm{mg}$ 0.5\% hyperbaric bupivacaine. Furthermore, Korhonen et $\mathrm{al}^{15}$. compared the use of a combination $3 \mathrm{mg}$ bupivacaine-10mcg fentanyl with $4 \mathrm{mg}$ bupivacaine in the other study. Mean discharge time was reported as 158 and 166 minutes in this study ${ }^{15}$.

In our study, patients included in group 1 started to feel pain at about $41^{\text {th }}$ minute at post-operative period. Analgesics were administered to patients. Pain decreased to acceptable level at about 60-90 minutes (mean 75 minutes). Patients were planned to be discharged when they got sufficient score from PADSS. On the other hand, patients in group 2 were allowed to be discharged from hospital when a micturition difficulty was relieved in addition to ensure PADSS criteria. Despite being close to the starting time of pain, patients descibed tingling or discomfort rather than pain. Therefore, these suffers were not considered as a pain when patients were scored by PADSS. To conlude, mean discharge time was determined as 116 minutes for patients participated in group 1 whilst it was 160 minutes for those included in group 2 . These durations were consistent with other studies.

Additionally, Harsten et $\mathrm{al}^{16}$ evaluated the effects of administration type of anesthesia, either SA or GA on the time for discharge from hospital in patients underwent knee arthroscopy. Time for being ready to discharge was determined as 46 hours in patients underwent GA whilst it was slightly longer in SA group (52 hours). However, there was not a significant difference in patients in mean of returning to the daily life. In addition, the reasons for delay in discharge processes of appropriate patients were also studied in the same study ${ }^{16}$. The most common cause was determined as organisational matter. Other reasons included general weakness, dizziness and pain.

Moreover, an extensive study was conducted by Pavlin et $\mathrm{al}^{5}$ to determine the factors affecting discharge timing in adult outpatients. 1088 patients were included in the study lasted for eight months. Reasons for delayed discharge were categorised into two groups. First group incuded medical issues. The most commonly observed medical problems included pain, nausea-vomiting, lethargy, persistant regional block and difficulty in micturition $^{5}$. On the other hand, systemrelated obstacles that were $41 \%$ of total reasons were collected in the second group. The most common form of problem was the absence of companion at time of anesthetic administration (53\%). Other 
reasons included overloaded work on nurses that manage the official processes of discharge (20\%) and lack in preparation of required medication (17\%). Preliminary results suggested that both male and female patients reveals different behavioral characteristics depending on the type of surgery. For instance, discharge time in male patients was determined quite similar within two group of patients received either SA or GA for surgery of lower extremities. However, it was determined to be 44 minutes longer in female patients administered with SA in comparison to GA.

Mentioned factors especially included in group 2 (system-related obstacles) were also the case in this study. The latter gender difference may be partially affected our work. Because the number of our female patients was higher by $10 \%$ in Group 2 compared to Group 1.

To conclude, unilateral SA by $0.5 \%$ hyperbaric bupivacaine is an effective method in arthroscopic knee surgery of outpatients compared with GA generated by propofol-desflurane. There are a number of advantages of using SA including that SA has a lower rate of complications and side-effects such as nausea and vomiting and decrease the requirement of post-opertaive analgesics. Therefore, use of SA leads to a high rate of patient satisfation and makes early discharge possible.

\section{REFERENCES}

1. Morgan GE, Mikhail MS, Murray MJ. Çev. Tulunay M, Cuhruk H. Klinik anesteziyoloji 2008; 4: 856.

2. Borghi B, Stagni F, Bugamelli S, Paini M, Nepoti M, Montebugnoli M, Casati A. Unilateral spinal block for outpatient knee artroscopy: A dose finding study. Journal of Clinical Anesthesia 2003; 15: 351-6.

3. Bridenbaugh OP, Grene MN, Brull SJ, Spinal Neural Blockade. In. Neural Blockade in Clinical Anesthesia and Management of Pain: Eds. Cousins MJ, Bridenbaugh OP. Third Edition. PhiladelphiaNew York: Lippincott-Raven publishers 1998; 203-41.
4. Mulroy MF, Larkin KL, Hadgson PS. A comparison of spinal, epidural, and general anesthesia for outpatient anesthesia. Anesth Analg 2000; 91: 860-4.

5. Pavlin DJ, Rapp SE, Poissar NL. Factors affecting discharge time in adult outpatients. Anesth Analg 1998; 87: 816-26.

6. Chan VW, Peng P, Chinyanga H, Lazarou S,Weinbren J, Kaszas Z. Determining minimum effective anesthetic concentration of hyperbaric bupivacaine for spinal anesthesia. Anesth Analg 2000; 90: 1135-40.

7. Ben-David B, Levin H, Solomon E. Spinal bupivacaine in ambulatory surgery: the effect of saline dilution. Anesth Analg 1996; 83: 716-20.

8. Biboulet P, Deschodt J, Aubas P. Continuous spinal anaesthesia: does low-dose plain or hyperbaric bupivacaine allow the performance of hip surgery in the elderly? Reg Anaesth 1993; 18: 170-5.

9. Enk D. Unilateral spinal anaesthesia: gadget or tool? Curr Opin Anaesthesiology 1998; 11: 511-5.

10. Toker K, Müezzinoğlu S, Canatay H, Kilıçkan L, Gürkan Y. Artroskopik diz cerrahisinde farklı anestezi yöntemlerinin karşılaştırılması. Türk Anest Rean Cem Mecmuasi 2002; 30: 408-12.

11. Bhat R, Malhotra SK, Dhillon MS. A prospective, randomized comparison of low dose bupivacaine spinal anaesthesia versus local anaesthesia with propofol infusion for knee arthroscopy. Anaesth Pain\&Intensive Care 2012; 16: 2430.

12. Korhonen MA, Valanne VJ, Jokela MR, Ravaska P, Korttila TK. A comparison of selective spinal anesthesia with hyperbaric bupivacaine and general anesthesia with desflurane for outpatient knee arthroscopy. Anesth Analg 2004; 99: 1668-73.

13. Koltka K, Abdülkerimov V, Küçükay S, Şentürk M, Pembeci K. Diz artroskopilerinde unilateral 
spinal anestezi ve genel anestezi uygulamalarının derlenme özellikleri açısından karşılaştırılması. Türk Anest Rean Der Dergisi 2008; 36: 310-6.

14. Korhonen M A, Valanne V, Jokela

15. Borghi B, Anelati D, Berti M, Torri G. Regionel anaesthesia for outpatient knee arthroscopy: A randomized clinical comparison of two different anaesthetic techniques. Acta Anaesthesiol Scand 2000; 44: 543-7.

16. Korhonen M A, Valanne V, Jokela M R, Ravaska P, Korttila K. Intrathecal hyperbaric bupivacaine 3 $\mathrm{mg}+$ fentanyl $10 \mu \mathrm{g}$ for outpatient knee arthroscopy with tourniquet. Acta Anaesthesiol Scand 2003; 47: 342-6.

17. Harsten A, Kehlet H, ToksvigLarsen S. Recovery after total intravenous general anaesthesia or spinal anaesthesia for total knee arthroplasty: A Randomized Trial. Br J Anaesth 2013; 111: 391-9.
M R, Ravaska P, Korttila K. Intrathecal hyperbaric bupivacaine 3 $\mathrm{mg}+$ fentanyl $10 \mu \mathrm{g}$ for outpatient knee arthroscopy with tourniquet. Acta Anaesthesiol Scand, 2003; 47: 342-346. 